УДК 398.3:392.81:[394.25(497.7)(049.3)

https://doi.org/10.55302/MF2180101m

Зоранчо Малинов

\title{
ТРИМЕРСКАТА ОБРЕДНОСТ ВО МАКЕДОНИЈА (СО ПОСЕБЕН ОСВРТ НА ГРАДОТ СТРУМИЦА)
}

Апстракт: Првите три дена од велигденскиот пост во некои македонски краеви се познати како Тримери и имаат посебно место во традицискиот народен календар. Бидејќ и се поврзани со датирањето на Велигден, Тримерите немаат постојан датум во календарот и вообичаено се паѓаат во втората половина на февруари или во првата половина на март. Обредноста што се практикувала во овој тридневен период, во традициската култура, покрај со обредното чистење на куќата на Чист понеделник (првиот ден од постот), главно се поврзува и со најстрог пост на којшто се подложувале некои категории луѓе, односно целосно воздржување од консумирање храна и пијалаци, така што во некои случаи не било дозволено ниту пиење вода. Овој специфичен тридневен пост кај народот е познат како йримерење или йримир, а на него вообичаено се подложуваат девојките стасани за мажење, со цел да го прочистат организмот (телесно и духовно), како и да ја докажат својата упорност и издржливост.

Заедничкото здружување, пак, на неколку тримирџики во една просторија, со цел полесно да се издржи тримирот, етнолозите го споредуваат со архаичниот иницијациски обред на девојките во адолесцентска возраст, кои се подложуваат на разни обреди, при кои, меѓу другото, се подложувале и на разни постапки со кои се проверувала и нивната упорност и издржливост во посебни обредни куќи, за да ја докажат својата подготвеност за стапување во брак. Оваа теза уште повеќе ја поткрепува случајот со обичајот на тримерење во Струмица, каде што на тримир, во минатото, задолжително се подложувале армасаните девојки, т.е. свршениците, на кои им претстои стапување во брак. Кога кон ова ќе се додаде и организирањето на „Струмичкиот карневал“ во вторникот од Тримерите, како што беше до пред една деценија, јасно е зошто во современото македонско општество Струмица, на некој начин, претставува парадигма за Тримери.

Клучни зборови: Тримери, тримерење (тримир), велигденски пост, „Струмички карневал“.

Првите три дена од велигденскиот пост во некои македонски краеви се познати како Тримери и имаат посебно место во традицискиот народен календар. Обредноста во овој тридневен период е поврзана со обреднообичајниот комплекс што го придружува празникот Проштени поклади (Прочка) и деновите што следуваат по него. Тука, пред сѐ, спаѓаат обредната покладна вечера пред седумнеделниот пост, најдолгиот пост во обредниот календар на православните христијани, како и деновите од првата седмица од велигденскиот пост. Бидејќи се поврзани со датирањето на Велигден, Тримерите, како и Прочка и Тодорица (Тодоровата сабота) немаат постојан датум во календарот и вообичаено се паѓаат во втората половина на февруари или во првата половина на март. Самиот назив Тримери за првите три дена од велигденскиот пост се доведува во корелација со грчкото: Трєı $\mu \varepsilon \dot{\rho} \varepsilon \varsigma=$ „трис мерес“, т.е. три денови), со значење на тридневен пост, кој вообичаено се разликува од останатите денови на пост во кои не е дозволено консумирање 
храна од животинско потекло. Имено, според традициските норми, верниците што ќе се одлучат на тримерење (тримир) се подложуваат на најстрог пост, односно целосно воздржување од консумирање храна и пијалоци, така што во некои случаи не е дозволено ниту пиење вода (Делиниколова 1960: 153; Китевски 2001: 90; инф.: Ф. Г. М.).

Периодот на пост без внесување на каква било храна во организмот трае од завршетокот на покладната вечера (во неделата на Прочка), па до причеста - во средата по литургијата. На овој специфичен тридневен пост, кој, според верувањето, се практикува - за здравје, најчесто се подложувале девојките стасани за мажење и некои постари жени, додека мажите и повеќето од жените во зрела доба поретко го практикувале. Според толкувањето на некои информаторки, целта на овој обред е да го прочистат организмот (телесно и духовно), т.е. очистување од евентуално сторените гревови, а на некој начин тоа се сфаќало и како докажување на својата издржливост и упорност (Малинов 2006: 138). Дека тримерењето не било едноставно ни сведочат кажувањата и записите дека понекогаш се случувало на тримирџиките да им испукаат и усните од дехидратацијата, а според некои кажувања тримерењето, во многу ретки случаи, завршувало и со несакан фатален епилог. Починатите тримирџики имале третман на самоубијци и нив „не ги пеел поп“, односно биле погребувани без опело - црковен обред за покој на душата. Според некои кажувања и записи, пак, доколку некоја девојка почине за време на тримерењето, како на пример во некои села во Егејска Македонија, од Драмско до Костурско, или пак во некои села во Тиквеш и во Пелагонија (Прилепско-битолско Поле), таа ќе биде закопана без црквени обреди и на буниште (ѓубриште) (АИФ, п. 38, 13; АИФ, п. 34, 12; АИФ, п. 28, 20; АИФ, п. 29, 17).

Тримерењето, односно спроведувањето на најстрог пост во првите три дена од велигденскиот пост во традициската култура на Македонците најчесто било застапено во јужните и во централните предели на македонскиот етнографски простор, поточно во речиси сите предели на егејскиот и на пиринскиот дел на Македонија, како и во некои од пределите на вардарскиот дел на Македонија. ${ }^{1}$ Освен тримерењето (тримир), односно подложувањето на

\footnotetext{
1 За распространетоста на тримерската обредност кај Македонците, како и за тоа какви обичаи и верувања ја следеле оваа обредност дознаваме од разни етнографски и етнолошки монографски трудови и статии за одделни предели и региони, како што се трудовите на: Атанасије Петровиќ (1907) - за Скопска Црна Гора, Стеван Тановиќ (1927) - за гевгелискиот крај, Миленко С. Филиповиќ (1939) - за Скопската Котлина, Зорка Делиниколова (1960) - за Радовиш, Рајна Дражева (1980) - за пиринскиот крај (Пиринска Македонија), Зоранчо Малинов (2006) - за Шопско-брегалничката етнографска целина и др., а исто така користени се и архивски материјали од Архивот на Институтот за фолклор „Марко Цепенков“, кои се издадени скенирани во ЦДформат, од каде што се искористени податоци за тримерската обредност во пределите: Драмско, Серско, Долновардарско (Гуменџе), Воденско, Костурско, Леринско, Битолско, Прилепско, Тиквеш, Кичевско, Дебарско и др.
} 
тридневен целосен, најстрог пост, во некои случаи, во периодот на Тримерите и во првите денови од велигденскиот пост се практикувал и поинаков вид пост, познат како еяноничење, яничење или ничење. Имено, во некои предели, покрај тридневното тримерење, односно подложување на целосен пост, постоел и обичај да се пости на тој начин што само еднаш во денот се консумирало храна, вообичаено храна што не била зготвена, туку само свеж зеленчук и овошје. При ваквиот начин на постење се јаде еднаш во денот, и тоа, попладне или приквечер, штом се појават првите sвезди на небескиот свод. Дничење (едноничење) можело да се практикува само еден ден, и тоа, вообичаено на Чист понеделник - првиот ден од велигденскиот пост, а некои едноничеле (ничеле) до три дена, т.е. за време на Тримерите ${ }^{2}$. Ваквиот начин на пост со консумирање храна само по еднаш во денот, можел да трае најмногу до саботата од првата седмица на велигденскиот пост, кај народот позната како Тодорова седмица, т.е. до празникот Тодорица (Тодорова сабота), кога и се причестувале в црква.

Празнувањето на неколкудневниот период околу почетокот на велигденските пости, односно деновите околу празникот Прочка (Велики поклади), вклучително и на тридневниот период - Тримери и на деновите од првата седмица од велигденските пости има посебно место во обредниот календар кај православното христијанско население во сите македонски краеви, а секако и кај православното население во градот Струмица. Самото прославување на Прочка, празник што има променлив датум и секогаш се паѓa во седмата недела пред Велигден, во традициската култура на струмичани може да се констатира дека не се разликува премногу од вообичаените обредно-обичајни постапки што се вршат и кај останатото македонско православно население. Како такви, на пример, можат да се сметаат обичајот на барање прошка на помладите од постарите, како и посетата на кумовите и барање прошка од нив. Како релативно познати обичаи можат да се сметаат и амкањето (ламкање) со варено јајце и палењето на конецот со кое било врзано јајцето - за да се гата за здравјето и касметот („К’смет“, среќа) на членовите на семејството во текот на претстојниот период. Исто така, како општопознати обреди би ги споменале и палењето на обредни огнови на маалски принцип и обредната покладна вечера во кругот на семејството кога, за последен пат, пред претстојниот седумнеделен пост, се консумира мрсна храна: јајца и млечни производи, додека со запостувањето од месо, според традициските норми, се започнува уште во претходната недела, на Месни поклади. Во однос на општопознатите обичаи и постапки што се практикувале во овој период од

\footnotetext{
${ }^{2}$ Со оглед на тоа што тримерењето не бил едноставен пост, во Костурско, на пример, тримереле само чупите (девојките) и младите невести, а постарите едноничеле (АИФ, п. 34, 12). Во селата на Скопска Црна Гора, пак, на почетокот од XX век во целата прва седмица од велигденските пости не се готвело, туку се јадела само свежа храна. Некои баби едноничеле („едноничив“), така што јаделе леб само еднаш во текот на денот, а некои, пак, тримереле (,тримерив“), така што во три дена јаделе само еднаш (Петровић 1907: 445).
} 
обредниот календар на ниво на Македонија и пошироко, слично може да се констатира и за практикувањето на обредното чистење на домовите и на покуќнината во првиот ден од велигденските пости - на Чист понеделник, кој всушност претставува и првиот ден од Тримерите.

Но, она што ѝ дава посебен белег на обичајната традиција на струмичани во однос на обредноста поврзана со покладувањето и запостувањето во овој период од годината претставуваат некои од обичаите што се извршуваат во првите три дена од велигденскиот пост, односно во периодот познат како Тримери. Имено, во минатото многу девојки и некои постари жени го практикувале обредот тримерење (тримир), односно целосно воздржување од консумирање на каква било храна. Така, на пример, овде тримерењето кај девојките стасани за мажење најчесто се спроведувало колективно, така што во една куќа се собирале по повеќе девојки-тримерџики, вообичаено собрани по: роднински, маалски или другарски принцип. Во градот Струмица, според обичајната традиција, вообичаено повеќе тримерџики се собирале во куќа, каде што имало армасана (свршена) девојка, која во текот на есенско-зимскиот период од годината била армасана и ја очекувало свадба наскоро. Во подвигот на армасницата во успешното завршување на тримерскиот обред поддршка ѝ давале нејзините немажени другарки, роднини и сосетки.

Уште поспецифичен, пак, обичај што се поврзува со традицијата на струмичани, споредено со традиционалната култура во однос на населението од останатите македонски градови и села, каде што се практикувал тримерскиот обред, претставува обичајот на посетата на домовите на армасаните (свршените) девојки околу пладнето на третиот ден од Тримерите. Имено, според традицијата, обичај е во средата по успешно завршениот тримерски пост, сите девојки што тримереле, сабајлето, да отидат в црква и да се причестат со нафора и светена вода - ајазмо, вообичаено од осветената вода што се чува од Богојавление (Водици) за оваа пригода (Василевска-Трајчевска 2013: 112)3 . Но, во Струмица постои и посебен обичај, според кој, треба да се посетат армасаните девојки, при што се одвивала и посебна свеченост. Имено, неколку роднини од страна на момчето ја посетуваат армасницата, носејќи при тоа и богати дарови во вид на облека и разно овошје и посни јадења, како еден вид награда за успешното завршување на тримерењето. Според обичајот, по успешнозавршеното тримерење на идната снаа, свекрвата испраќа три синии со подароци, кои ги носат деца - машки и женски, за децата што ќе ги

\footnotetext{
${ }^{3}$ Во некои тиквешки села, на пример, тие што тримереле, во средата оделе в црква и се напивале прво од оставената крстена вода од Водици - „ајазмо“, а потоа дома јаделе компот, овошје и друга лесна храна, затоа што три дена не јаделе ништо и потешка храна ќе им наштети на здравјето (АИФ, п. 28, 20). Во некои кичевски села, пак, тие што тримереле, во средата пиеле вода оставена од Водици, и со тоа се сметало дека зеле половина причесна. Тогаш во црквата секој носел проскура панагија за на(ф)ора. По земањето ајазмо ужинале малку и пак тримереле до Тодорица, кога се причестувале (АИФ, п. 21, 13).
} 
роди да бидат мешани, т.е. и од двата пола. Во првата синија има разна облека спакувана како за во бовча: фустан, блуза, пантофли, домашен фустан (роба), копринено шалче и сл., во втората синија се носело разно сезонско овошје (емиш): јаболка, портокали, урми, леблебија со суво грозје и бонбони, а во третата синија се носела наутлија погача (чурек), мала чинија со „зерде“, т.е. благ ориз (се приготвува само со вода и шеќер, еден вид на „посен сутлијаш“, без млеко), локум и алва ${ }^{4}$. Кога трите синии со подароците ѝ се даваат на тримерџиката - армасаната девојка, некоја постара жена од роднините на момчето што била испратена од страна на свекрвата, ја благословува идната невеста со зборовите: „Поздрав од свекрвата оти си издржала пост три дена. Да бидете вечни, да бидете вековити ус деца, ус сѐ! Господ милост нек ви дава, честито нек ви е!“‘... (Василевска-Трајчевска 2013: 113-114).

На ваквите свечености, кои се организирале околу пладне во домот на армасницата (свршената девојка), присуствувале голем број гости, вообичаено жени од страната на момчето, од неколку десетици, а во некои случаи и повеќе од стотина (инф.: Ф. Г. М.). На гостите за ручек им се послужува исклучиво посна храна: посна сарма, со листови од кисела зелка, бел посен грав (непотпржен), ориз и сецкани ореви, потоа ошав (компот) од суви сливи, зерде, алва и сл., а од пијалоците задолжителна била бозата. На ваквите собири се пееле и посебни наменски „мрсни“ песни, т.е. песни со еротска содржина, со цел - армасницата, идната невеста, да се подготви за обврските што ја очекуваат во брачниот живот (Василевска-Трајчевска 2013: 113-114; Котев 2018: 27-46; инф.: Ф. Г. М.).

Овие семејни свечености во минатото (до средината на минатиот век) често прераснувале и во еден вид општа градска веселба, бидејќи армасниците со гостите заминувале на локалитетот Цареви Кули - ридот над градот Струмица со остатоците од средновековната тврдина, каде што се собирале и по неколку стотици луѓе. Покрај разните јадења што славениците ги носеле со себе во кошници, овде, на Цареви Кули, трговците продавале и: симити, ѓевреци, алва, кикиритки, боза и сл., а имало и музика за да се зголеми веселбата со песни и ора. Во минатото, овде се спроведувал и обичајот, секоја армасана девојка да се напие од водата што тече од каменот на темелот на источната страна на тврдината, која се смета за света вода, а целта на обредот била - армасницата во бракот да има пород

\footnotetext{
${ }^{4}$ Сличен обичај на носење на синии со посни јадења што ги носеле деца во средата од Тримерите на свршениците (армасаници), кои успешно оттримереле, е регистриран и во соседниот Радовиш, но без да се споменат синии со подароци во вид на облека од страна на свекрвата, како и посета на роднини од страна на момчето на нејзиниот дом (Делиниколова 1960: 153). За сличностите во приготвувањето на посната трпеза за третиот ден (средата) од Тримери во Прилеп, но и за посебните посни специјалитети во овој град, како на пример, варена пченица со конопни зрна, дознаваме од вебстраницата: https://radiopela.mk/prilepchanki-deneska-go-praznuvaat-trimir-trimir-praznikza-armasanite-devojki/
} 
Од друга страна, пак, исто така нешто посебно што ја издвојува обичајно-обредната традиција на струмичани во однос на останатото население во Македонија претставува и организирањето на обредни поворки со маскирани учесници, обред, кој со текот на времето прерасна во културна манифестација со називот „Струмички карневал“. Имено, според традицијата на струмичани, на втората вечер од Тримерите, во вторникот спроти средата, армасникот требал да ја посети својата армасница во вечерните часови во нејзиниот дом за време на тримерењето. Посетата се реализирала со уште неколку негови другари-ергени, и тоа маскирани, така што армасницата да не може веднаш да го препознае својот иден брачен сопатник. Момчињата армасаните и ергените, за оваа вечер се подготвувале со денови за изработката на својата маска, а некои пак во минатото купувале и посебни маски набавени дури и од Солун. Се носеле најразлични маски, од оние изработени од животински кожи, па до маски на ѓаволи со рогови, вампири со големи заби, караконџули и други страшни ликови и митолошки суштества, а некои се преоблекувале како попови и сл. Така преоблечени и маскирани, момчињата другарите на армасникот, доаѓале во домот на армасницата, а според обичајот, таа требало да го препознае својот свршеник. Според верувањето, доколку веднаш го препознаела, во тој случај во бракот ќе имале касмет - к'смет (среќa), а во спротивно, доколку не го препознаела - ќе ги следело несреќа. За да не се случи второво, армасникот, како знак на распознавање, носел некаков „нишан“ под маскирната облека, во некои случаи и некаков предмет со фалусоиден облик. Откако армасаната девојка ќе си го „препознаела“ момчето, следувала богата трпеза со посни јадења за гостите, а потоа се пееле и разни песни и се играле ора до раните утрински часови (ВасилевскаТрајчевска 2013: 109).

Според некои толкувања, од маскираните момчиња, кои претрчувале низ улиците на Струмица, движејќи се кон куќите на армасаните девојки, подоцна произлегол и „Струмичкиот карневал“ со маскирани поворки. Во секој случај, автентичните обредни поворки што се движеа низ струмичките улици беа поврзани со втората вечер од тримерскиот период, но од 2012 година, во согласност со одлуките на Организацискиот одбор на „Струмичкиот карневал“, неговото одржување, од прагматични причини, е поместено во саботата пред Прочка, со оглед на фактот што тогаш е викенд и луѓето се ослободени од работните обврски. Инаку, „Струмичкиот карневал“, како културна манифестација, се одржува од 1991 година, а во 1994 год. градот Струмица станува член на FECC - Федерација на европските карневалски градови. Во 1998 год. во Струмица се одржа и Годишниот конгрес на оваа федерација, така што градот Струмица и „Струмичкиот карневал“ на „голема врата“" влегоа на мапата на Европа и на светот како карневалски град. Во 2020 год. требаше да се одржи јубилејниот 30-ти карневал по ред, поточно неговата возобновена организирана форма, но, поради светската пандемија предизвикана од вирусот Ковид 19, тој беше одложен. „Струмичкиот карневал“" не се одржа и оваа 2021 година, но организаторите настојуваа во 
периодот на неговото одржување да се организираат разни изложби и слични придружни културни манифестации во согласност со протоколите за спречување на ширењето на пандемијата, со што, на симболичен начин, се одбележаа карневалските празнувања за кои струмичани, во изминатите години, се подготвуваа со месеци

Тримерењето, односно спроведувањето на најстрог пост во првите три дена од велигденскиот пост - Тримери, претставува обред што настанал под влијание на христијанството, но не може да се одреди со прецизност кога точно е востановен ваков вид на пост, и тоа, главно за одредена категорија на луѓе - најчесто за девојките стасани за мажење, свршениците (армасниците) и постарите жени. Податокот, пак, дека овој обред во Македонија, во нејзините географски граници, најмногу бил застапен во нејзините јужни делови, т.е. во Егејска Македонија и во јужните делови од пиринскиот и од вардарскиот дел на Македонија, како и самата етимологија на обредот и периодот кога тој се

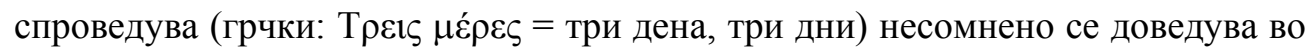
врска со христијанска традиција настаната под влијанието на грчката духовна култура.

Од друга страна, пак, според етнолозите, заедничкото здружување на неколку тримирџики во една просторија, за полесно да се издржи подвигот на тридневниот најстрог пост, го споредуваат со архаичните иницијациски обреди на девојките во адолесцентска возраст, кои биле подложувани на разни обреди, при кои, меѓу другото, се подложувале и на разни постапки со кои се проверувала нивната упорност и издржливост, и тоа во посебни обредни куќи, за да ја докажат својата подготвеност за стапување во брак. Оваа теза уште повеќе ја поткрепува случајот со обичајот на тримерење во Струмица, каде што на тримир, во минатото, задолжително се подложувале армасаните девојки, т.е. свршениците на кои им претстои стапување во брак. Не случајно, заради големото значење и заради важноста на обичаите што се практикувале во споменатиов тридневен период од годината во локалната традиционална култура на струмичани, Тримери, во овој крај, е познат и како „празник на армасаните“ (Сувариев 1998: 180) ${ }^{6}$. Кога, кон ова, ќе се додаде и организирањето на Струмичкиот карневал во вторникот од Тримерите, како

5 Повеќе информации за „Струмичкиот карневал“ можат да се проследат во трудовите: Сувариев 1998, Петровска-Кузманова 2009, Василевска-Трајчевска 2013, Витанова-Рингачева 2014, Урдин 2014, како и од официјалната веб-страница на „Струмичкиот карневал“ (http://www.strumickikarneval.com/index.php/mk/) и некои весници (https://www.novamakedonija.com.mk/zivot/magazin/co-симболични-акти...).

${ }^{6}$ Според податоците добиени од информаторката Фимка Гогова-Михајлова, до пред некоја деценија дуќаните (продавниците) во Струмица во средата од Тримери затворале во 2 часот попладне (како да е празник), бидејќи речиси сите жени во градот биле ангажирани во посета на некоја од армасниците што тримереле. Некои од жените што работеле во смени, се заменувале или земале слободен ден (инф.: Ф. Г. М.). 
што беше до пред една деценија, како и масовното учество на струмичани во организацијата и во посетата на оваа културна манифестација, јасно е зошто во современото македонско општество Струмица на некој начин претставува парадигма за Тримери.

\section{ЛИТЕРАТУРА}

\section{Кирилични изданија}

Василевска-Трајчевска, Н. 2013. Празнувањейо на Прошйени йоклаяи

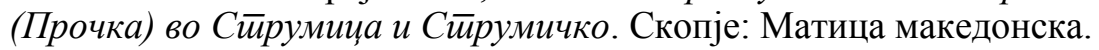

Витанова-Рингачева, А. 2014. „Функцијата на обредите со маски и нивна манифестација во тримерските празнувања и карневалот во Струмица“.

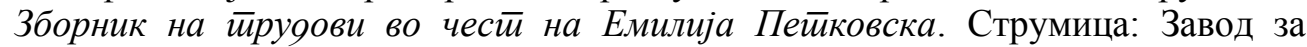
заштита на спомениците на културата и музеј - Струмица, 311-321.

Делиниколова, 3. 1960. „Обичаи сврзани со поедини празници и неделни дни во Радовиш“. Гласник на Еӣнолошкиой музеј во Скойје, 1. Скопје: Етнолошки музеј на Македонија, 135-178.

Дражева, Р. 1980. „Календарни празници и обичаи“. Пирински край.

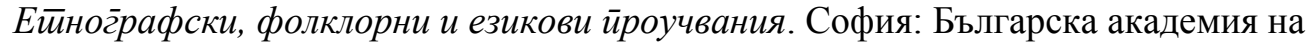
науките, Етнографски институт с музей.

Китевски, М. 2001. Макеgонски йразници. Скопје: Менора.

Котев, И. 2018. Иірале моми йо месечина (Еройска нарояна йоезија и

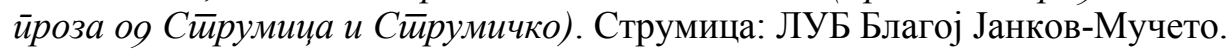

Малинов, 3. 2006. Траяицискиой нарояен каленоар на Шойско-

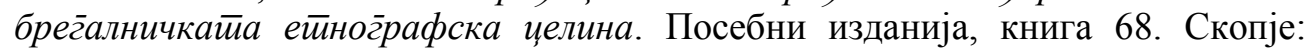
Институт за фолклор „Марко Цепенков“.

Петровић, А. 1907. Нарояни живот̄ и обичаји у Скойској ирној г̄ори. Српски етнографски зборник, књига седма, Обичаји народа српскога, књига прва. Београд: Српска Краљевска Академија.

Петровска-Кузманова, К. 2009. Карневалийе во Макеgонија. Посебни изданија, книга 75. Скопје: Институт за фолклор „Марко Цепенков““.

Сувариев, И. 1995. „Тримери во Струмица“, Ейнолог, бр. 6. Скопје: Здружение на етнолозите на Македонија, 193-196.

Сувариев, И. 1998. „Обичаи со маски застапени во зимскиот календар на народни празници со осврт на струмичкиот карневал и неговото потекло“. Зборник на трудови од Меѓународниот симпозиум „Обичаи со маски“ Вевчани - Струга 1996. Скопје: Музеј на Македонија, 177-181.

Тановић, С. 1927. Срӣски нарояни обичаји у Ђевђелијској кази, Српски етнографски зборник, књ. XL, Живот и обичаји народни, књ. 16. БеоградЗемун: Српска Краљевска Академија.

Урдин, К. 2014. „Како беше возобновен Струмичкиот карневал по

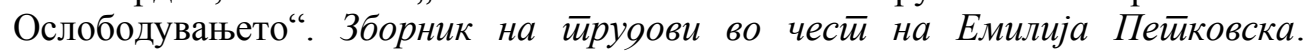
Струмица: Завод за заштита на спомениците на културата и музеј - Струмица, 297-309. 
Филиповић, М. С. 1939. Обичаји и веровања у Скойској койлини, Српски етнографски зборник, књ. LIV, друго одељење, Живот и обичаји народни, књ. 24. Београд: Српска Краљевска Академија.

\section{Архивски материјали}

Архив на Институтот за фолклор, папка бр. 21. Славејкова, В. 1953. Празнични обичаи во Кичевија, 1-62.

Архив на Институтот за фолклор, папка бр. 23. Славејкова, В. 1954. Празнични обичаи во Дебарско Поле и Жуйа, 1-50.

Архив на Институтот за фолклор, папка бр. 28. Славејкова, В. 1956. Празнични обичаи во Тиквеш, 1-42.

Архив на Институтот за фолклор, папка бр. 29. Славејкова, В. и Русиќ, Б. 1953. Празнични обичаи во Прилейско-бийолско Поле, 1-65.

Архив на Институтот за фолклор, папка бр. 33. Јосифовски, Ј. 1954. Празнични обичаи во Леринско, Егеејска Макеоонија, 1-33.

Архив на Институтот за фолклор, папка бр. 34. Јосифовски, Ј. 1954. Празнични обичаи во Косӣурско и Пресӣа, Егејска Макеоонија, 1-32.

Архив на Институтот за фолклор, папка бр. 35. Јосифовски, Ј. 1954. Празнични обичаи во Серско, Егејска Макеоонија, 1-35.

Архив на Институтот за фолклор, папка бр. 36. Јосифовски, Ј. 1954. Празнични обичаи во Вооенско, Егеејска Макеоонија, 1-16.

Архив на Институтот за фолклор, папка бр. 37. Јосифовски, Ј. 1954. Празнични обичаи во Долноваряарско (Гумение), Егејска Макеоонија, 1-16.

Архив на Институтот за фолклор, папка бр. 38. Јосифовски, Ј. 1954. Празнични обичаи во Драмско, Егејска Макеоонија, 1-32.

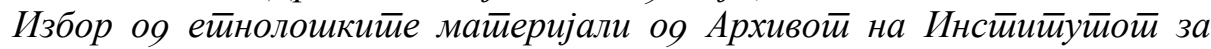
фолклор „Марко Цеиеенков“ за йериояой 1952-1962 (ЦД-формат). Изборот од архивските материјали го приредиле: д-р Весна Петреска и д-р Зоранчо Малинов. Скопје: Институт за фолклор „Марко Цепенков“.

\section{Интервју}

Фимка Гогова-Михајлова (информатор, родена 1942 год. во Струмица) во разговор со авторот на 04.09.2020 год. во Струмица (личен запис).

\section{Сајтографија}

„Струмички карневал“ http://www.strumickikarneval.com/index.php/mk/ [Пристапено на 20.09.2021].

„Со симболични активности се одбележува 'Струмички карневал 2021'““ https://www.novamakedonija.com.mk/zivot/magazin/со-симболични-активностисе-одбележу/ [Пристапено на 20.09.2021].

„'Тримир' празник за армасаните девојки - адет на Прилепчани“ https://radiopela.mk/prilepchanki-deneska-go-praznuvaat-trimir-trimir-praznik-zaarmasanite-devojki/ [Пристапено на 20.09.2021]. 
Zorančo Malinov

\title{
THE CUSTOM OF “TRIMERI” (A THREE DAY COMPLETE FASTING) IN MACEDONIA (WITH A SPECIAL REVIEW OF THE CITY OF STRUMICA)
}

\author{
Summary
}

The first three days of the Great Lent in some Macedonian regions are known as "Trimeri" (a three day complete fasting) and have a special place in the traditional folk calendar. Because they are related to the date of Easter, this period of three days does not have a fixed date on the calendar and usually falls in the second half of February or the first half of March. The rituals that were practiced in this three-day period, in the traditional culture, in addition to the ritual cleaning of the house on Clean Monday (the first day of the Great Lent), is generally associated with the strictest fast to which some categories of people were subjected, i.e. complete abstinence from consumption of food and drinks and in some cases even drinking water was not allowed. This specific three-day fasting is popularly known as "trimerenje" or "trimir", and it is usually performed by girls who are ready for marriage, in order to purify the body (physically and spiritually), as well as to prove their perseverance and endurance.

The joint association of several "trimirdzhiki" (girls that undergo the three-day fast) in one room, in order to make the "trimir" easier to endure, is compared by an ethnologist, with the archaic initiation ritual of adolescent girls, that undergo various rituals in which, among other things, they undergo various procedures that check their persistence and endurance in special ritual houses, in order to prove their readiness for marriage. This thesis is further supported by the case of the custom of "trimerenje" in Strumica, where in the past the fiancées, i.e. the girls who are about to get married, were obliged to the three-day total fasting. When we add to this the organization of the Strumica Carnival on the first Tuesday of the Great Lent, as it was a decade ago, it is clear why in the modern Macedonian society Strumica is in a way a paradigm for "Trimeri". 


\section{ПРИЛОЗИ \\ Фотографии}

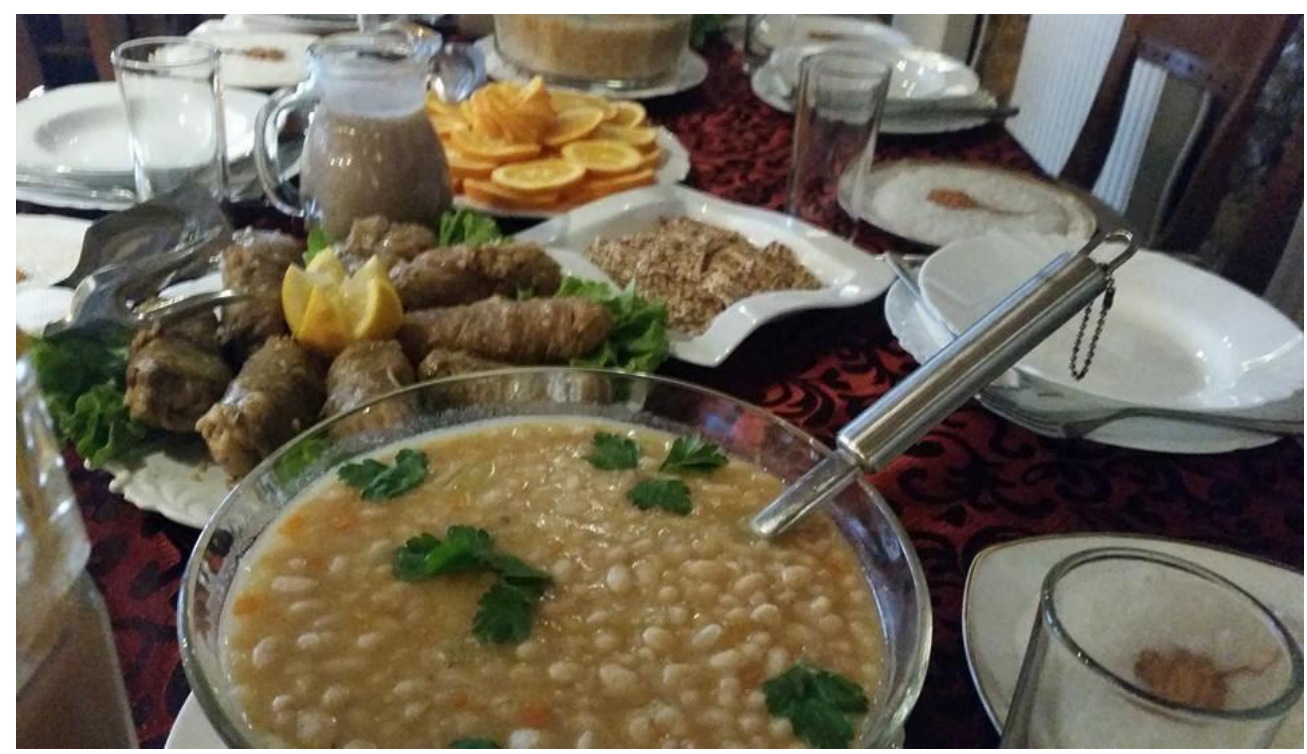

Дел од тримерската трпеза во средата, за пречек на гостите: посен грав, посна сарма, зерде, боза.

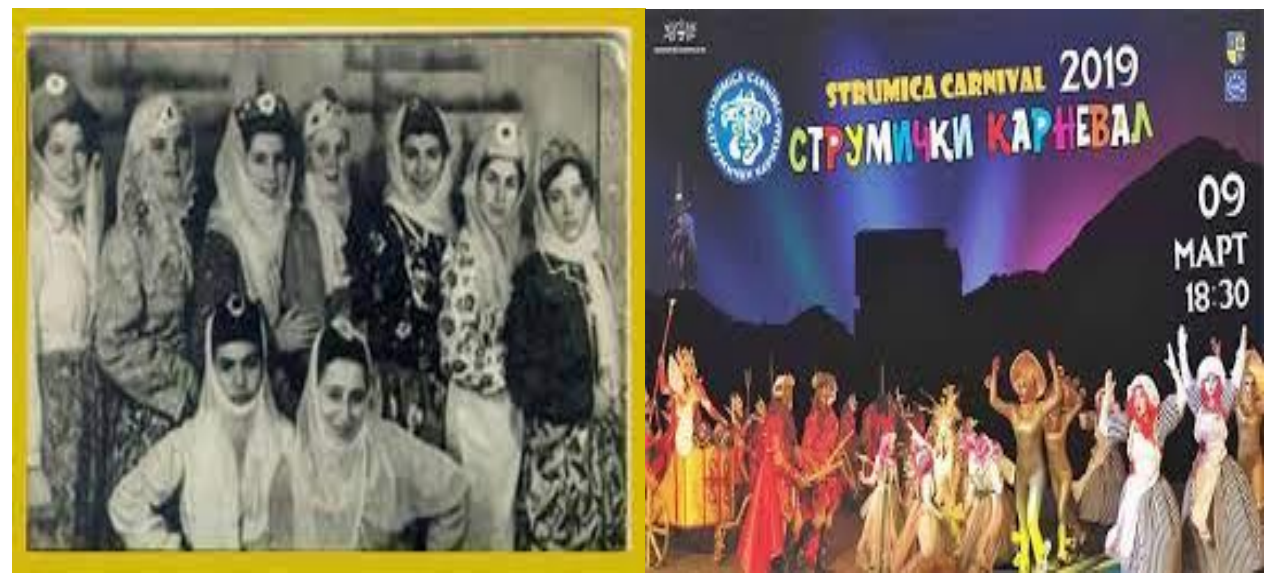

Архаична форма на маскирање за Тримери.
Дел од атмосферата на Струмичкиот карневал во 2019 г. 
